\title{
Landscape Waste Composting with the Aid of Effective Microorganisms using Mechanical Crusher Machine
}

\section{Mimi Suliza Muhamad ${ }^{1 *}$, Muhammad Qusyairi Abdul Rahman², Nuramidah Hamidon $^{1}$, Nor Hazren Abdul Hamid ${ }^{1}$, Norshuhaila Mohamed Sunar ${ }^{1}$, Hasnida Harun ${ }^{1}$, Roslinda Ali ${ }^{1}$}

\begin{abstract}
${ }^{1}$ Sustainable Environmental Technology (SET) Focus Group, Advanced Technology Centre, Faculty of Engineering Technology, Universiti Tun Hussein Onn Malaysia, Pagoh Higher Education Hub, 84600 Pagoh, Johor, MALAYSIA

${ }^{2}$ Centre for Diploma Studies, Department of Mechanical Engineering,

Universiti Tun Hussein Onn Malaysia, Pagoh Higher Education Hub, 84600 Pagoh, Johor, MALAYSIA

* Corresponding Author

DOI: https://doi.org/10.30880/jaita.2020.01.01.002

Received 15 February 2020; Accepted 06 April 2020; Available online 30 June 2020

Abstract: Malaysia is facing an uncontrolled increase in municipal solid waste generation due to population growth and nation development. Part of the waste that is disposed to landfill is landscape waste. The disposal of these waste can be reduced by composting method. In this study, the compost is produced by using a mechanical crusher machine for 1 hour and stored in a bin for weeks. The form compost had temperature and $\mathrm{pH}$ in the acceptable range for fertilizer but low moisture content. The $\mathrm{C}: \mathrm{N}$ and $\mathrm{C}$ : $\mathrm{P}$ ratio is higher than the optimum range for fertilizer. The increased concentration of effective microorganisms leads to a higher content of $\mathrm{C}, \mathrm{N}$, and $\mathrm{P}$, in which the maximum $\mathrm{N}$ content was obtained for sample C60 with $32.9 \mathrm{mg} / \mathrm{L}$. While for $\mathrm{P}$ and $\mathrm{K}$ content was $11.32 \mathrm{mg} / \mathrm{L}$ and $77300 \mathrm{mg} / \mathrm{L}$, respectively in sample A60. All the samples also show low heavy metals contents except for zinc.
\end{abstract}

Keywords: Landscape waste, Compost, Mechanical crusher machine, Effective microorganisms

\section{Introduction}

Globalization and urbanization in Malaysia had increased the rate of waste production. Municipal solid waste (MSW), commonly known as refuse or rubbish, is discarded from residential, commercial, and institutional areas [1]. Malaysia is facing an uncontrolled increase of MSW generation due to population, economic growth, and industrialization. The rapid growth of the economy and population had caused MSW to proliferate by $28 \%$ a decade from 5.6 Mt in 1997 to $7.65 \mathrm{Mt}$ in 2007. This was predicted to further increase by $30 \%$ in 2020 and $39 \%$ in 2030 compared to the baseline year of 2007. Despite government efforts, waste management remains one of the critical environmental issues in Malaysia [1]. Generation of solid waste per capita in Malaysia is about $1.1 \mathrm{~kg} / \mathrm{day}$. Over 26,500 tonnes of solid waste was disposed of almost solely through 166 operating landfills in the country every day. Regardless of other means in disposal, a landfill is the most widely accepted and prevalent method for MSW disposal in developing countries

The use of organic fertilizers is a major component of organic farming practices. Organic manures can provide the essential plant nutrients and enhance crop productivity, but also leave a beneficial residual effect on succeeding crops. Various kinds of organic materials such as animal manures, sewage sludge, and crop residues are applied to the soil to 
improve soil organic matter content [2]. Chemical fertilizers contain trace amounts of heavy metals and metalloids. Continuous application of chemical fertilizers during the past fifty years may have contributed to the increase of heavy metals and metalloids in the soil and groundwater aquifers [3]. This could reduce soil fertility and crop productivity in the long term. Soil degradation will threaten food security and increase the emission of carbon dioxide that will cause global warming and affect the environment [4].

Landscape waste is organic or gardens waste such as leaves and trimmings of plants. Some organic items, such as grass clippings and dirt are excluded from the curbside collection. Yard waste and food waste account for $60 \%$ of MSW generated. Fresh yard trimmings are organic materials that can be composted and improve soil productivity. Fresh yard trimmings differ from other composted materials as they are less processed and more biologically active [6].

Most land waste is a beneficial soil modification because it is a good source of plant nutrients and organic matter [7]. Warm and humid environments will likely generate a higher fraction of wetter, more readily decomposable yard trim than colder and drier areas. Various components of yard waste are expected to degrade at different rates and potential for methane generation based on their percentage of moisture, total volatile solids, and carbon to nitrogen ratio [8]

The major problem involved in recycling the waste material is slow release rates of nutrients during the decomposition of organic materials. Microorganisms can enhance the efficiency of organic systems and these organisms create conditions which favor mutual support and enable them to compete with harmful pathogens. By reducing the amount of chemical fertilizer consumption, microbial fertilizers can clean the environment and promote the productivity capacity of the soil. Microorganisms are important in agriculture to help supply plant nutrients and reduce inorganic fertilizer requirements [9].

Effective microorganisms (EM) are a microbial culture of a naturally occurring assortment of beneficial microorganisms such as photosynthetic bacteria (Rhodopseudomonas plastris and Rhodobacter sphacrodes), lactic acid bacteria (Lactobacillus plantarum, L. casei, and Streptococcus lactis), yeast (Saccharomyces spp), actinomycetes (Strptomyces spp.) and fermenting fun [10]. EM are commercially available in a liquid that contains a variety of lactic acid bacteria, yeasts, and phototrophic bacteria. It helps to speed up the decomposition of organic matters and releasing nutrients to the soil. EM has a unique ability to minimize the risk factors which may contribute towards the onset of pathological problems in plants and animals [9].

\section{Composting Process of the Landscape Waste}

The composting process of the landscape waste involves several stages include the collection of landscape waste, crushing, mixing, and collection of compost material. The collection of landscape waste was conducted in the area of Universiti Tun Hussein Onn Malaysia, Pagoh Higher Education Hub, Johor. The landscape waste consists of leaves and flowers, branches, twigs, grass and weeds. Landscape waste was generated due to the trimming of bushes for landscaping purposes and also natural fall of leaves, flowers, and twigs. The landscape waste was collected in a plastic bag and stored in a room before undergo the composting process. Next, the composting process was performed by using a mechanical crusher machine that was used by the agro-industry company, Sarjani (M) Sdn Bhd as shown in Figure. 1. The process involves shredding, mixing, and collection of the compost. The landscape waste and effective microorganisms (EM) were processed using this machine that was designed for composting production. This machine operates on $1.5 \mathrm{~kW}, 1400 \mathrm{RPM}, 50 \mathrm{~Hz}, 3.51$ amps and 415 volts using AC motor. It was equipped by a 3-phase induction motor. The collected landscape waste was fed into the shredder that crushes all the landscape waste into a smaller size. The shredder speed was $1400 \mathrm{rpm}$ and can crush large size material into a smaller part. Figure. 2 show the shredder compartment in the mechanical crusher machine. Landscape waste that has been shredded was then dropped into the mixing compartment as shown in Figure. 3. In these steps, the shredded landscape waste was mixed at a certain temperature. After that, the mixture was well blended with the EM injected during the process. The mixture was mixed for an hour. Then, the produced compost was dropped from the mixing compartment to the collection compartment as shown in Figure. 4. 


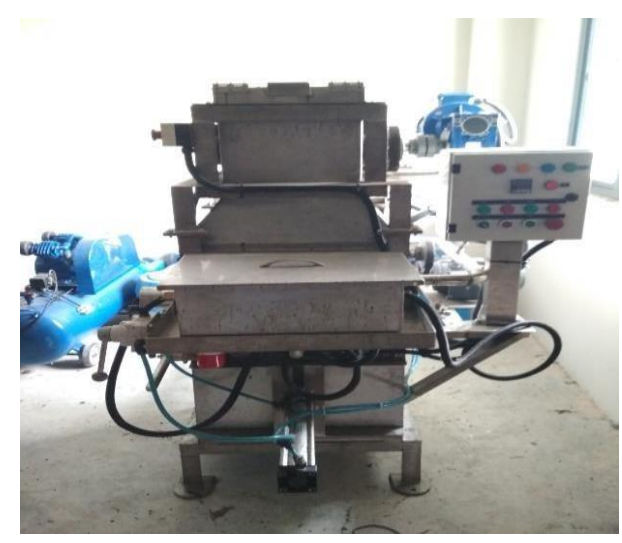

Fig. 1 - Mechanical crusher machine

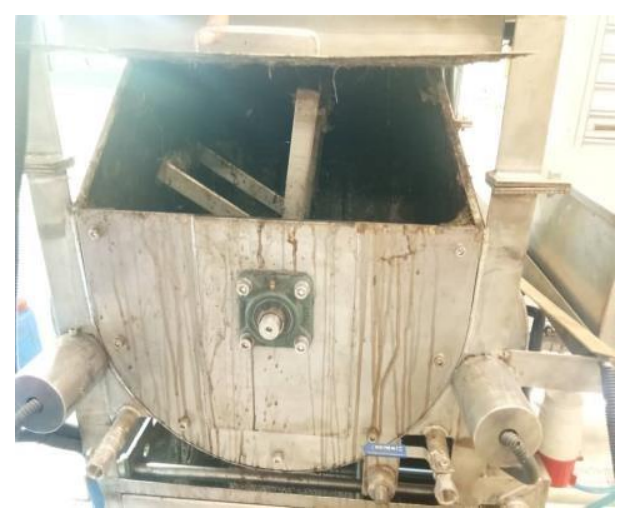

Fig. 3 - Mixing compartment

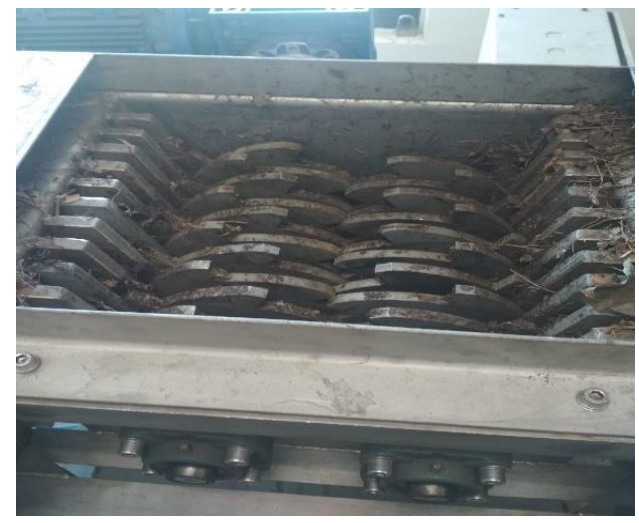

Fig. 2 - Shredder compartment

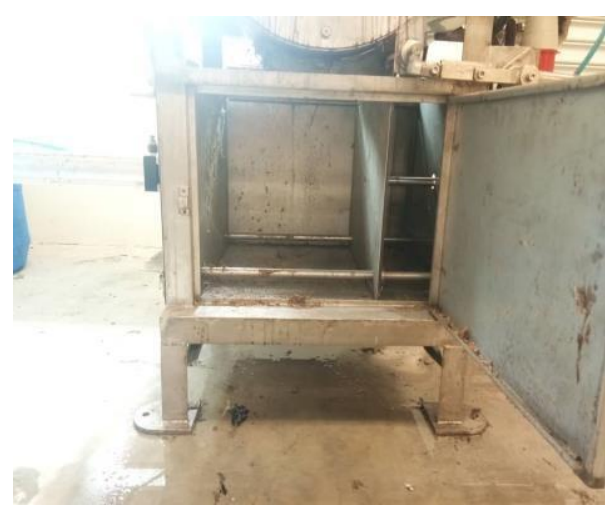

Fig. 4 - Collection compartment

\subsection{Characterization of Compost}

The triplicate of produced compost as shown in Figure. 5 - Figure. 7 (denote as A60, A70, A80, etc. with respect to the temperature of $60^{\circ} \mathrm{C}, 70^{\circ} \mathrm{C}$, and $80^{\circ} \mathrm{C}$ ) was characterized for temperature, $\mathrm{pH}$, moisture content, nitrogen, phosphorus, carbon, potassium, and heavy metals. A thermometer was used to measure the temperature of each sample obtained for 4 weeks after being stored in a bin for 2 weeks. The $\mathrm{pH}$ of the compost sample was measured using HQ440D Laboratory Multi-Parameter Meter (Hach) in the laboratory. For each sample, $10 \mathrm{~g}$ of the compost was mixed in $100 \mathrm{ml}$ of distilled water and measured for $\mathrm{pH}$. Energy dispersive X-Ray spectroscopy (EDX) analysis was used to analyze the elemental composition of carbon in the compost material. The sample was ground into the finest form and then dried in an oven for 24 hours at $110^{\circ} \mathrm{C}$ before undergoes coating for the analysis. The nitrogen content in the compost was analyzed using Uv-vis Spectrometer, DR6000 (Hach) according to Nessler method. The weight of the samples directly from the machine was weighted and the weight of samples after drying in the oven for $110^{\circ} \mathrm{C}$ for 24 hours was recorded. The moisture content of the compost material was calculated using Eqtn. 1.

$$
\text { Moisture content }(\%)=\frac{\text { Wetweight of sample (W1)-Dry weight of sample(W2) x 100 }}{\text { Wet weight of sample (W1) }}
$$

For heavy metals, the sample was digested with 5\% concentration of nitric acid before tested by using Inductive couple plasma-optical emission spectrometer (ICP-OES). The heavy metals detected were cadmium (Cd), chromium $(\mathrm{Cr})$, copper $(\mathrm{Cu})$, lead $(\mathrm{Pb})$, nickel $(\mathrm{Ni})$, and zinc $(\mathrm{Zn})$. In addition, phosphorus was also detected using ICP-OES 

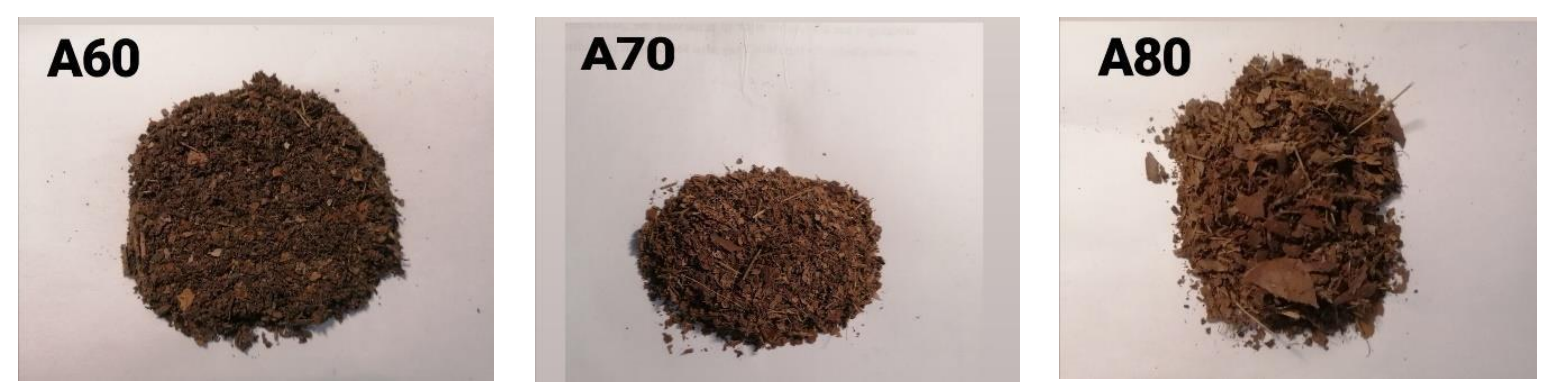

Fig. 5 - Sample A60, A70 and A80
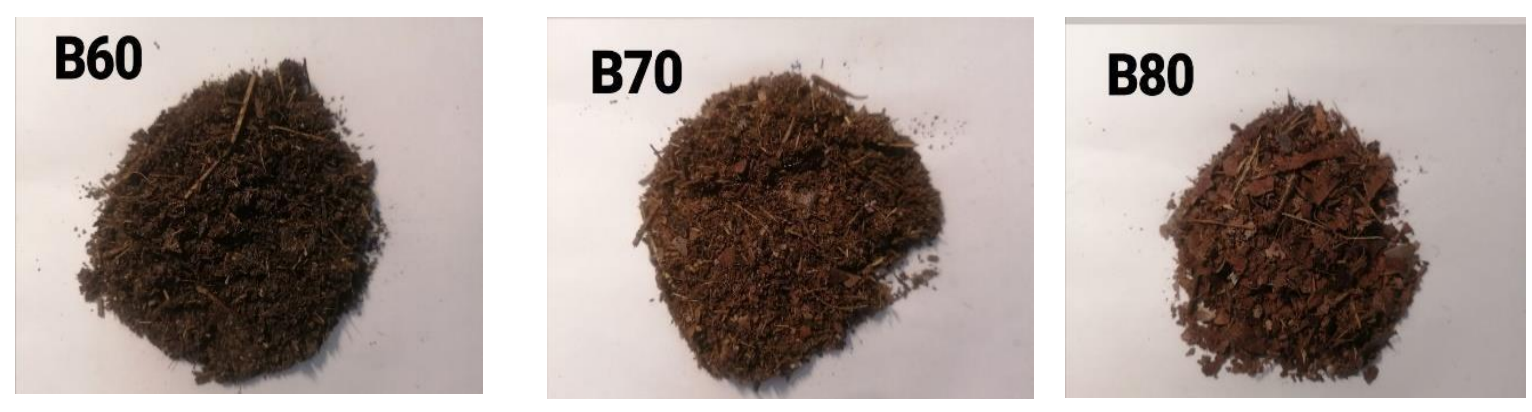

Fig. 6 - Sample B60, B70 and B80
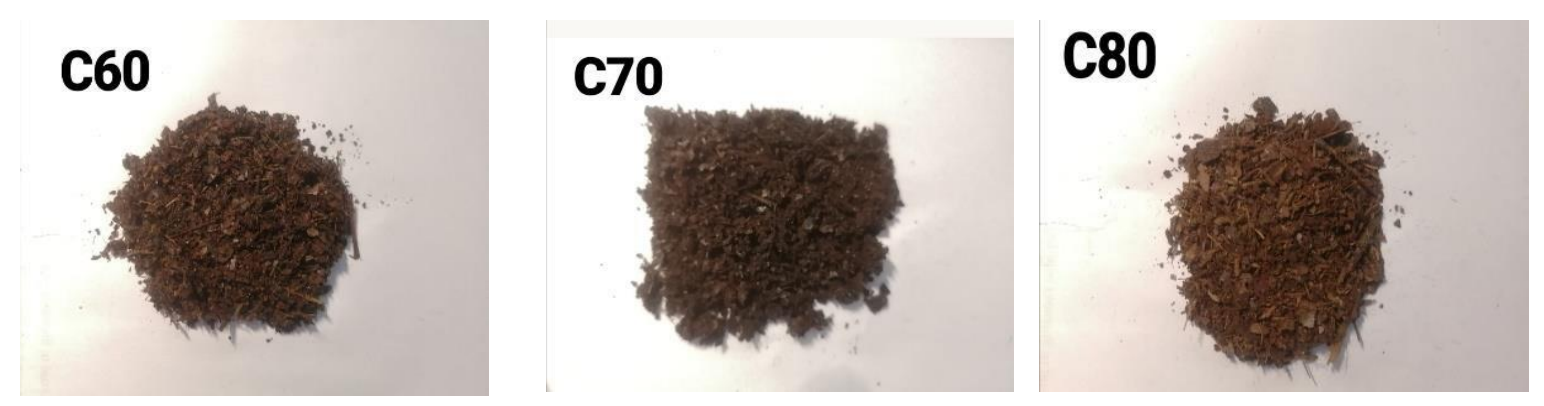

Fig. 7 - Sample C60, C70 and C80

\section{Results and Discussion}

The results and discussion were based on the temperature, $\mathrm{pH}$, and moisture content data that was collected after two weeks the compost kept in the bin. While for nitrogen, phosphorus, carbon, potassium and heavy metals data was collected after one month of the sample kept in the bin.

\subsection{Temperature}

Figure. 8 until 10 shows the temperature of the compost from week 1 to 4 . Based on Figure. 8, the temperature for sample A60, A70 and A80 decreases over 4 weeks with only slight increase for sample A80 during week 4. Similarly, Figure. 9 also show that the temperature for sample B60, B70 and B80 was decrease over the weeks with only slight increase for sample B70 during week 4. Figure. 10 show that the temperature for sample C60, C70 and C80 drop gradually from $31^{\circ} \mathrm{C}$ to $27^{\circ} \mathrm{C}$ over 4 weeks. These temperature patterns indicated the thermophilic, mesophilic and maturation phases of a composting process. The rapid progress from initial mesophilic phase to thermophilic indicates a high proportion of readily degradable substances an self-insulating capacity of the waste [11]. It is the natural digestion process by organisms that result in increased temperature within the compost. The temperature will be self-sustaining until the compost is stabilized. 


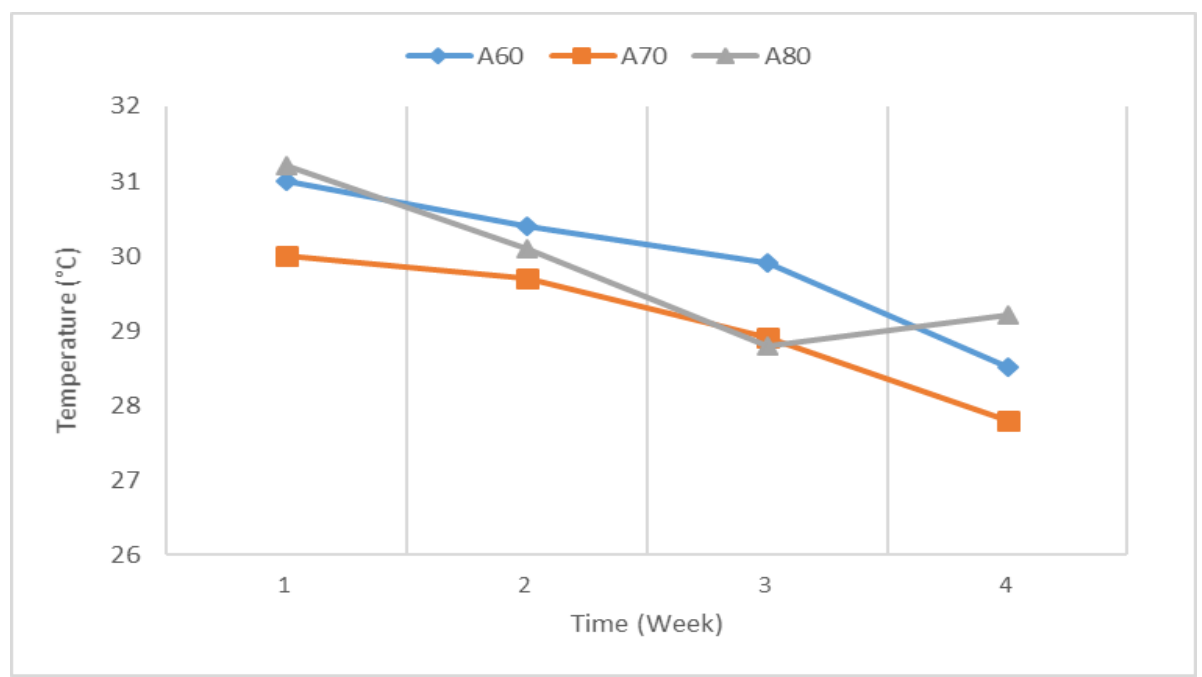

Fig. 8 - Temperature of compost versus time for sample A

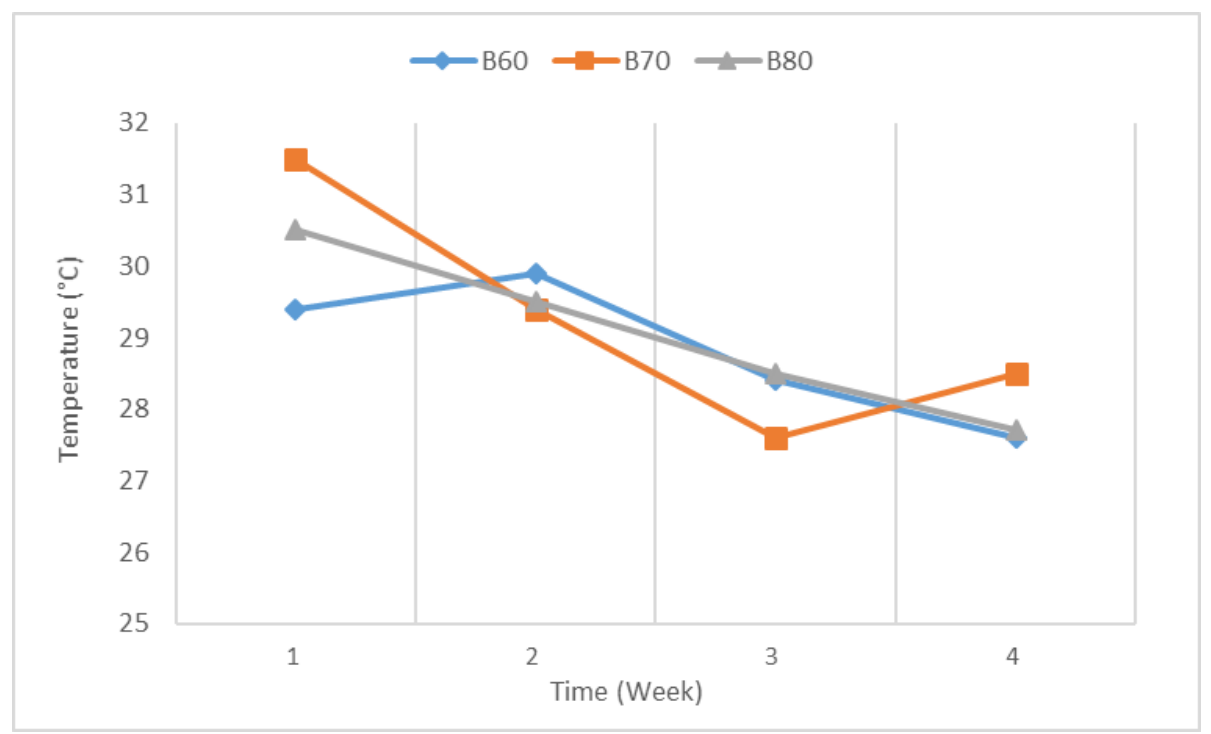

Fig. 9 - Temperature of compost versus time for sample B 


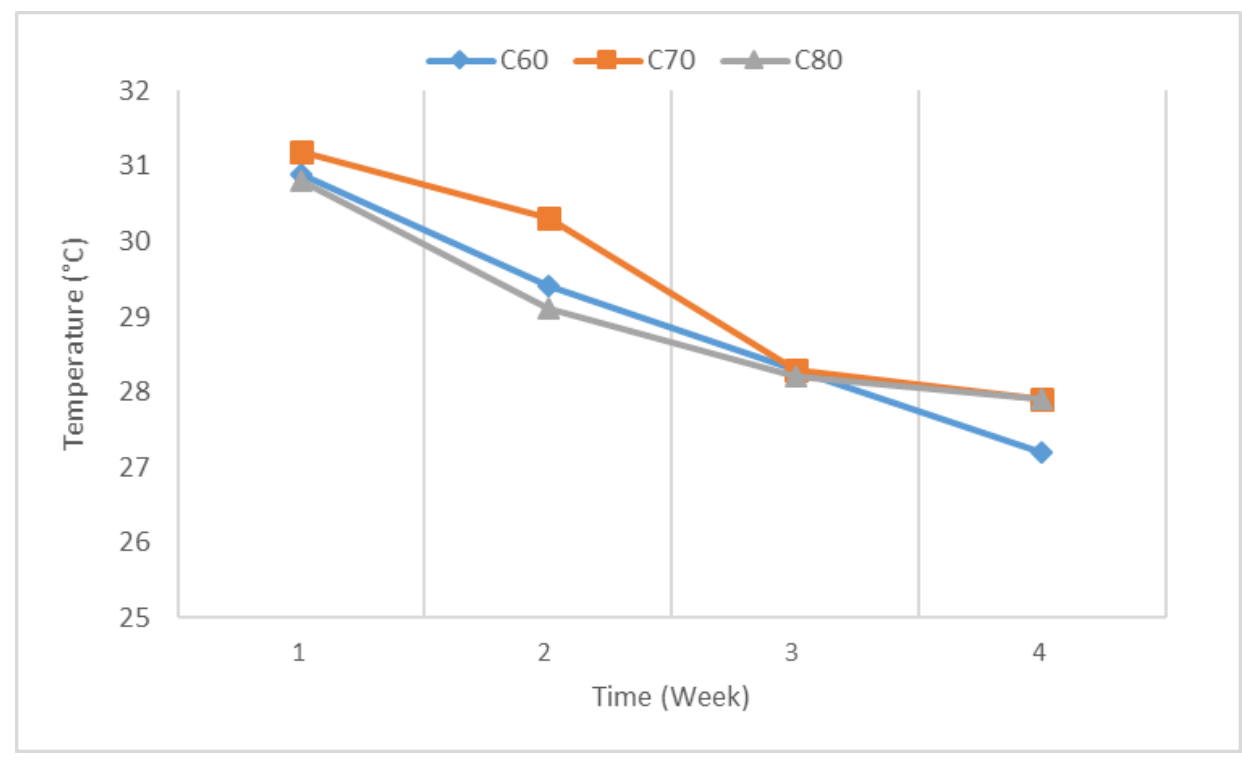

Fig. 10 - Temperature of compost versus time for sample $C$

\section{$3.2 \mathrm{pH}$}

Figure. 11 until 13 shows the $\mathrm{pH}$ of the compost from week 1 to 4 . Figure. 11 show that all sample A recorded $\mathrm{pH}$ ranging from $6.4-6.6$ for week 1 . The $\mathrm{pH}$ increases to 7.2- 7.5 in week 2 and slightly decrease in week 3 and week 4 to $\mathrm{pH}$ 7. Figure. 12 show the $\mathrm{pH}$ recorded for sample $\mathrm{B}$ was ranging from 5.7 to $6.5 \mathrm{in}$ week 1 . Then the $\mathrm{pH}$ increases to 7.0- 7.5 for week 2 and maintain in natural $\mathrm{pH}$ for week 3 and week 4. Figure. 13 show the $\mathrm{pH}$ for sample $\mathrm{C}$ ranging from $6.5-7.0$ in week 1 . The $\mathrm{pH}$ was then increased to 7.5- 8.0 in week 2 . On week 4, sample C70 recorded $\mathrm{pH}$ of 8.18.5 which was alkali. $\mathrm{pH}$ is a critical factor influencing the microbial activities and microbial community during composting. Under optimal conditions, the $\mathrm{pH}$ after an initial reduction should increase from acidic to neutral range if the organic acids are decomposed successfully where range of 7.0-8.0 is reported to be optimum for composting [12]

However, the $\mathrm{pH}$ values increased from the second week onwards because of the decomposition of proteins and the elimination of carbon dioxide [13]. The rise in $\mathrm{pH}$ during these week was considered to be the result of the metabolic degradation of organic matter containing nitrogen [11]. The relative increase in $\mathrm{pH}$ during the latter stage of the composting process might be due to the nitrification process which is responsible for the release of $\mathrm{H}^{+}$ion [11]. Sample $\mathrm{C}$ was mix with $900 \mathrm{ml}$ of $\mathrm{EM}$ and reach the highest $\mathrm{pH}$ of 8.34. Lowest $\mathrm{pH}$ was recorded in sample $\mathrm{B}$ which was mixed with $600 \mathrm{ml}$ of EM. All the $\mathrm{pH}$ at the end of the experiments was within the acceptable range of fertilizer.

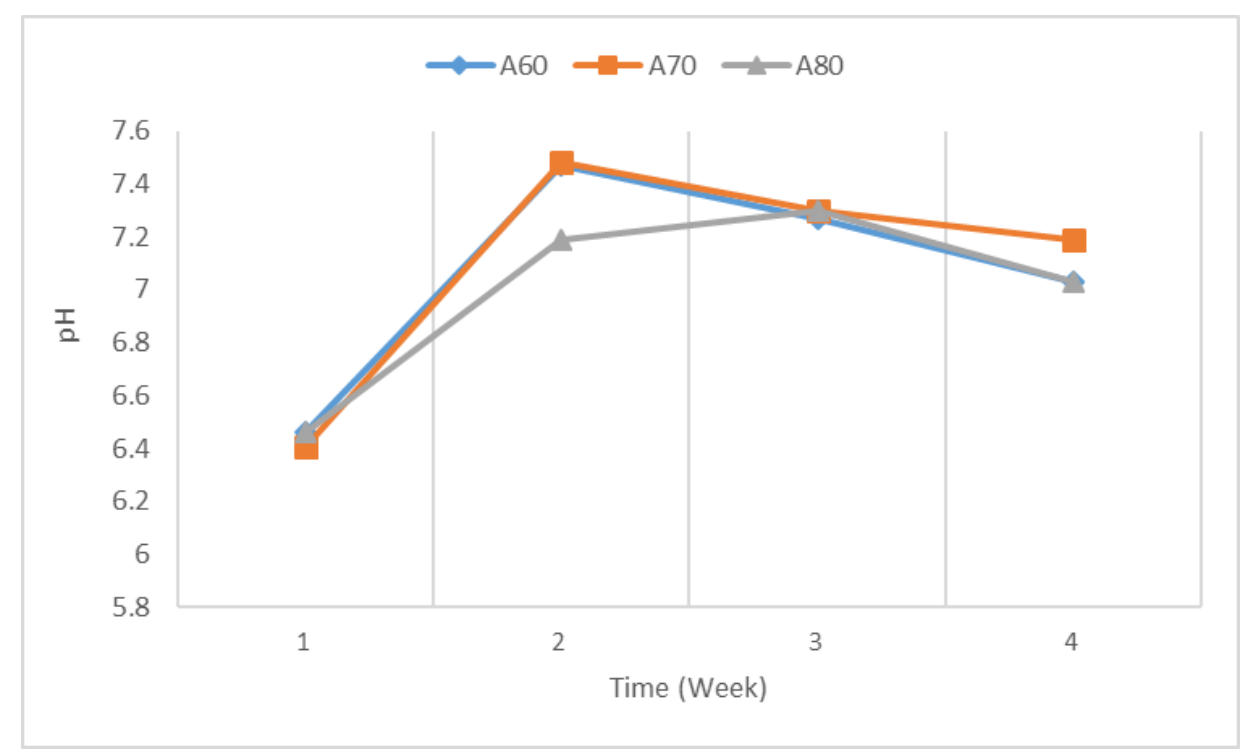

Fig. 11 - pH of compost versus time for sample A 


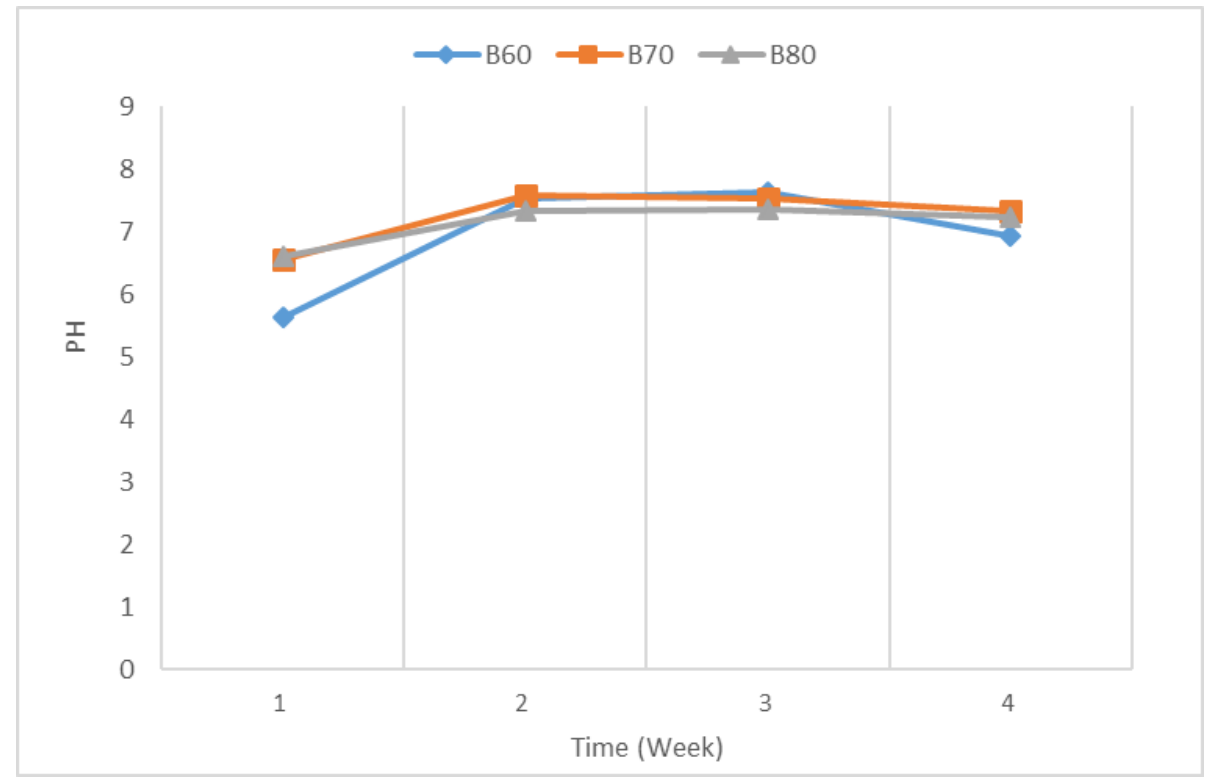

Fig. 12 - pH of compost versus time for sample B

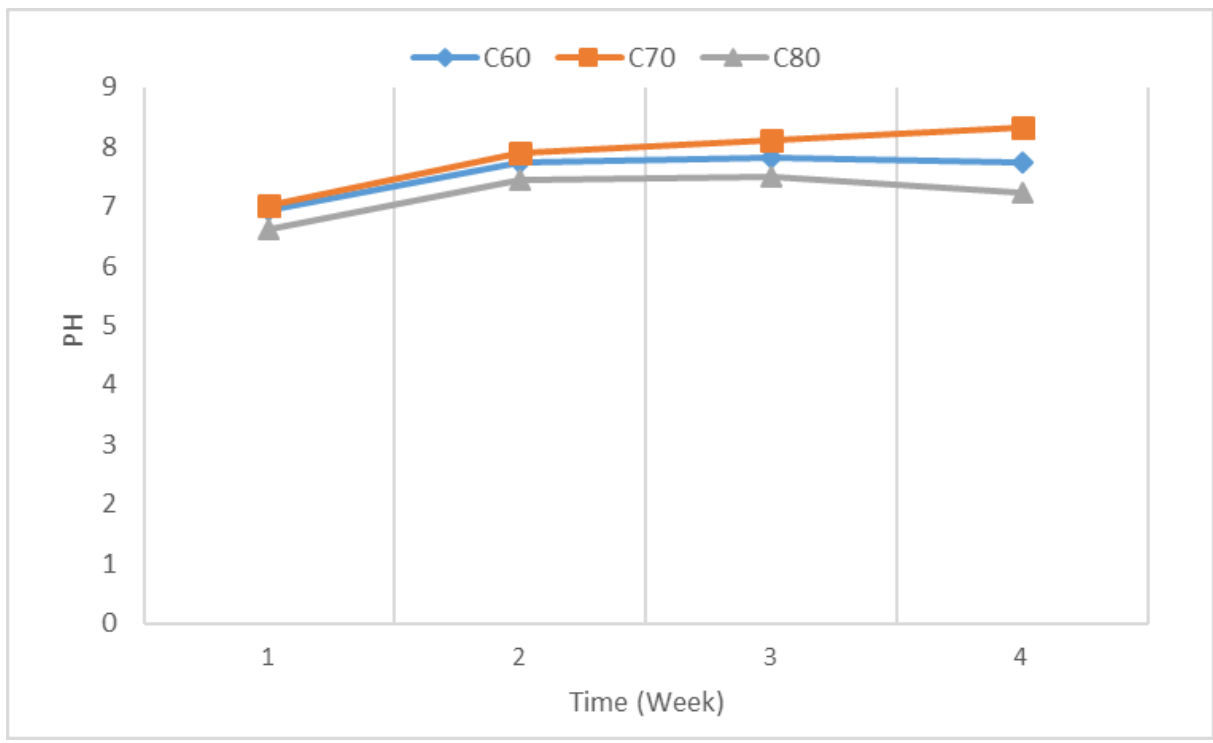

Fig. 13 - pH of compost versus time for sample $\mathrm{C}$

\subsection{Moisture Content}

Figure. 14 until Figure. 16 show the moisture content of the compost from week 1 to 4 . Figure. 14 show that the moisture content for sample A decrease from $38 \%$ in week 1 to $2.5 \%$ in week 4 . Figure. 15 show the moisture content for sample B drop from 52\% in week 1 to $12 \%$ in week 4. Figure. 16 show the moisture content for sample C also decrease from $52 \%$ in week 1 to $26 \%$ in week 4 . The decrease in moisture content might be due to absorption of water from the landscape waste.

The compost sample has an acceptable range of the optimum moisture content on the first week. The optimum moisture content obtained from the biodegradation of compost was between 50\% - 70\% [13]. The decomposition process can be performed successfully by microbes only if the moisture content is maintained between $40 \%$ - 60\% [14]. Moisture is necessary to dissolve nutrients for use as a food source by the microorganisms. Excessive moisture creates an undesirable anaerobic condition [15]. 


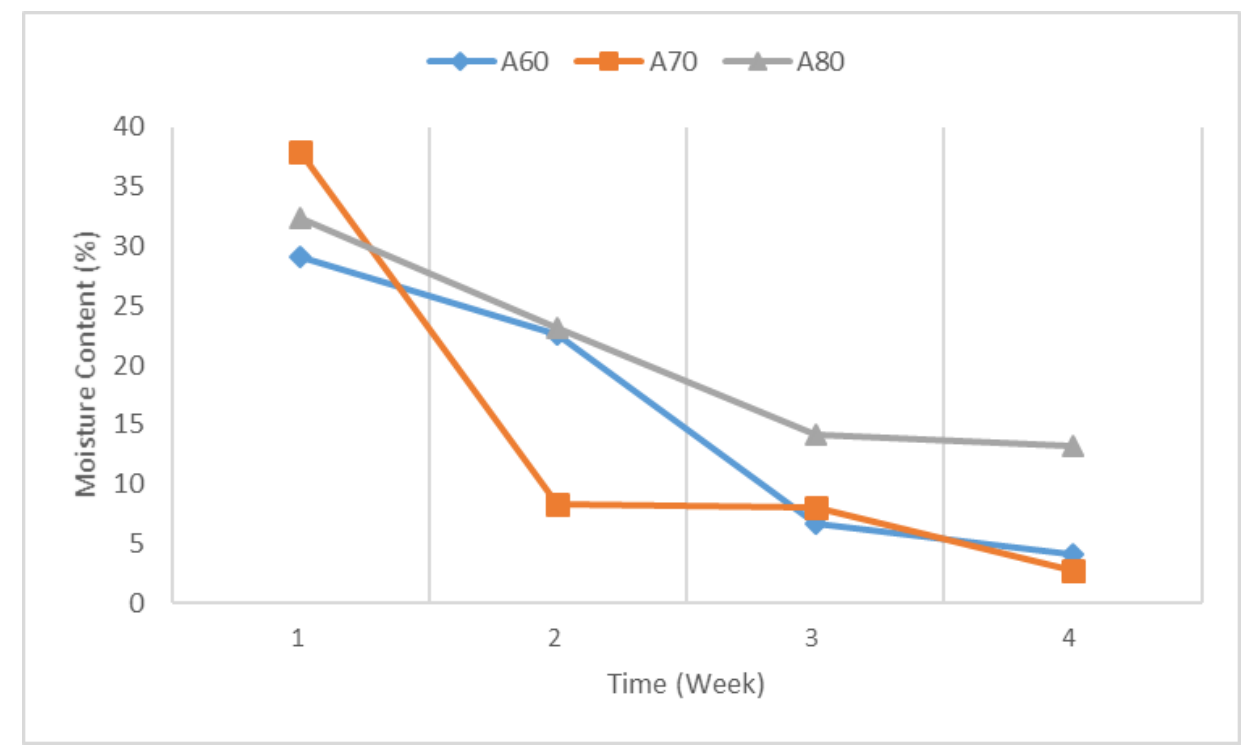

Fig. 14 - Moisture content of compost versus time for sample A

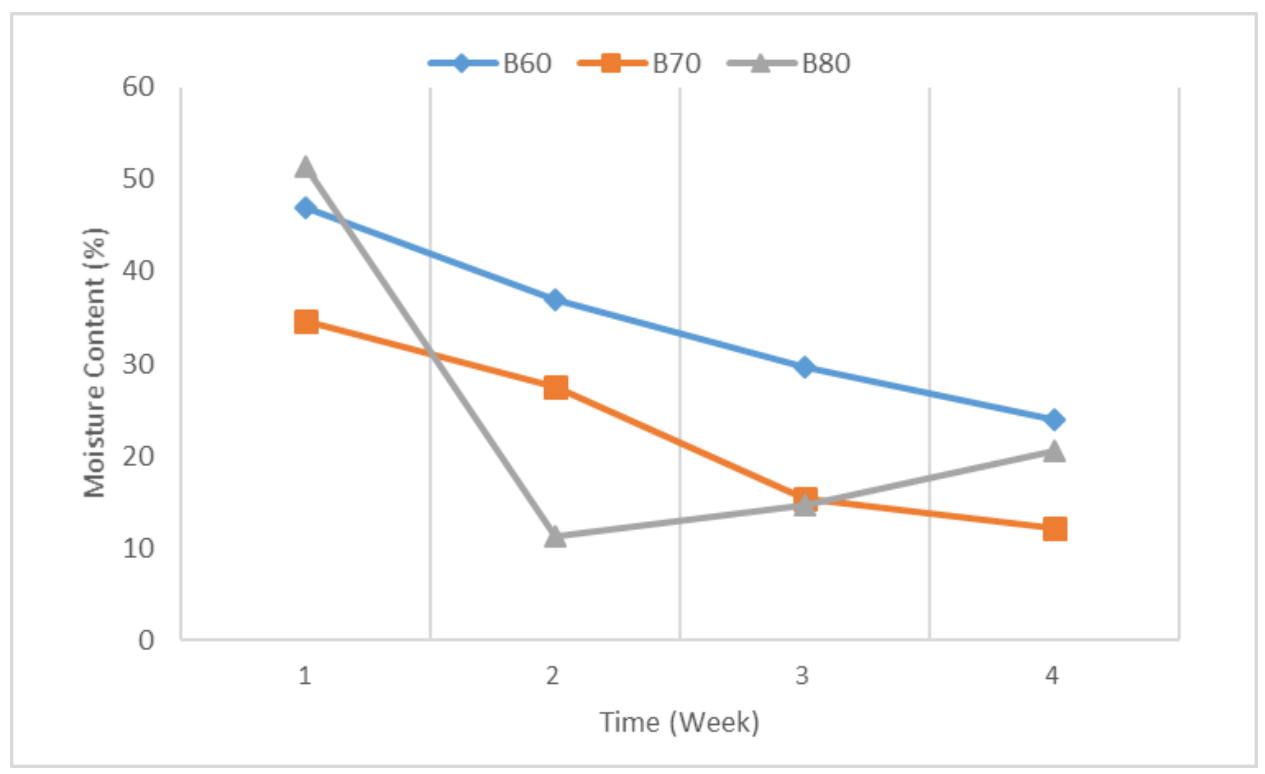

Fig. 15 - Moisture content of compost versus time for sample B 


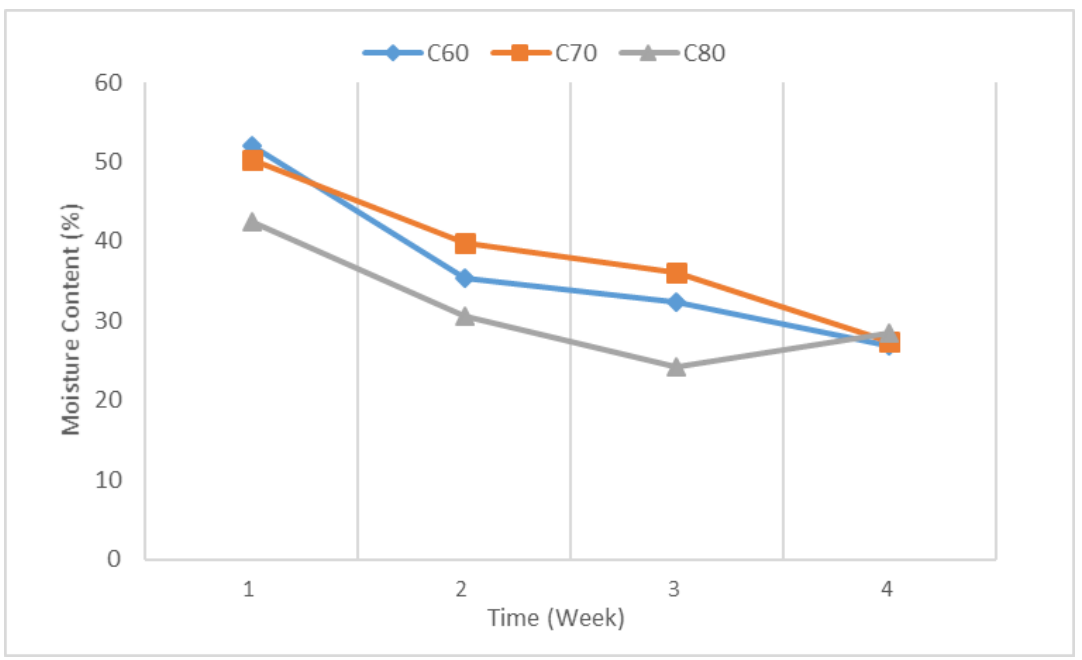

Fig. 16 - Moisture content of compost versus time for sample $\mathbf{C}$

\subsection{Carbon and Nitrogen Analysis}

The presence of carbon during composting assists microbes during the decomposition process, while nitrogen helps build microbial cell structures. However, excess of nitrogen leads to the emission of toxic ammonia gas, which can damage plant roots if the compost applied as fertilizer [13]. Table 1 show the $\mathrm{C}$ : $\mathrm{N}$ ratio of each compost samples. The $\mathrm{C}$ : $\mathrm{N}$ ratio was not in the optimum ratio due to the different machine that was used to detect the element of nitrogen that may affect the measurement. The optimum $C$ : $N$ ratio for a compost should be between 10:1 and 15:1. Compost products usually achieve C: $\mathrm{N}$ ratio of 10:1.

Table 1 - Carbon and nitrogen percentage of the compost

\begin{tabular}{cccc}
\hline Sample & Carbon $(\%)$ & Nitrogen $(\%)$ & C:N \\
\hline A60 & 42.48 & 0.00257 & $16529: 1$ \\
A70 & 60.93 & 0.00309 & $19718: 1$ \\
A80 & 59.96 & 0.00165 & $36339: 1$ \\
B60 & 55.60 & 0.00134 & $41492: 1$ \\
B70 & 61.76 & 0.00103 & $59961: 1$ \\
B80 & 55.51 & 0.00227 & $24453: 1$ \\
C60 & 54.58 & 0.00329 & $16589: 1$ \\
C70 & 59.88 & 0.00226 & $26495: 1$ \\
C80 & 63.02 & 0.00268 & $23514: 1$ \\
\hline
\end{tabular}

\subsection{Carbon and Phosphorus Analysis}

The release of mineral salts such as ammonium and phosphate during decomposition and mineralization of organic substances increased the composting process [16]. Table 2 show the C: P ratio for each of the samples. Similarly to the $\mathrm{C}: \mathrm{N}$ analysis, the ratio was higher than the optimum due to the different machine that was used to detect the element of phosphorus that may affect the measurement.

Table 2 - Carbon and phosphorus percentage of the compost

\begin{tabular}{cccc}
\hline Sample & Carbon (\%) & Phosphorus (\%) & C:P \\
\hline A60 & 42.48 & 0.00113 & $38618: 1$ \\
A70 & 60.93 & 0.00492 & $12186: 1$ \\
A80 & 59.96 & 0.001052 & $59960: 1$ \\
B60 & 55.60 & 0.00753 & $6950: 1$ \\
B70 & 61.76 & 0.00489 & $12352: 1$ \\
B80 & 55.51 & 0.00199 & $27755: 1$ \\
C60 & 54.58 & 0.00553 & $9096: 1$ \\
C70 & 59.88 & 0.00271 & $19960: 1$ \\
C80 & $\underline{63.02}$ & $\underline{0.00301}$ & $\underline{21006: 1}$ \\
\hline
\end{tabular}




\subsection{NPK}

The compost products will contain a small amount of ammonia nitrogen and nitrogen if $40 \%$ of the nitrogen was use during the composting process [15]. Maintaining the moisture content within its optimum range during the composting process increases the concentrations of phosphorus and potassium because of the volume reduction of organic waste [13]. Table 3 show the results collected from each sample for the nitrogen (N), phosphorus (P) and potassium (K) elements. The highest $\mathrm{N}$ content was recorded for sample $\mathrm{C} 60$ with $32.9 \mathrm{mg} / \mathrm{L}$. While, the highest $\mathrm{P}$ and $\mathrm{K}$ content was detected in sample A60 with $11.32 \mathrm{mg} / \mathrm{L}$ and $77300 \mathrm{mg} / \mathrm{L}$, respectively.

Table 3 - NPK content in the compost

\begin{tabular}{cccc}
\hline Sample & Nitrogen $(\mathrm{mg} / \mathrm{L})$ & Phosphorus $(\mathrm{mg} / \mathrm{L})$ & Potassium $(\%)$ \\
\hline A60 & 25.7 & 11.32 & 7.73 \\
A70 & 30.9 & 4.92 & 0.35 \\
A80 & 16.5 & 10.52 & 0.19 \\
B60 & 13.4 & 7.53 & 0.85 \\
B70 & 10.3 & 4.89 & 0.52 \\
B80 & 22.7 & 1.99 & 1.05 \\
C60 & 32.9 & 5.53 & 0.16 \\
C70 & 22.6 & 2.71 & 0.27 \\
C80 & 26.8 & 3.01 & 0.30 \\
\hline
\end{tabular}

\subsection{Heavy Metals}

High levels of heavy metals in composts is a concern if they are to be apply to food crops. Heavy metals do not degrade throughout the composting process and frequently become more concentrated due to the continuous loss of carbon and water into carbon dioxide and water vapour throughout the composting process. Metal concentrations that were measured in segregated food waste were related to the natural contents of metals in food and plant material wastes [17].

Table 4 show the heavy metal content of the compost sample. All of the compost sample has low content of heavy metals which were cadmium $(\mathrm{Cd})$, chromium $(\mathrm{Cr})$, copper $(\mathrm{Cu})$, nickel $(\mathrm{Ni})$ and lead $(\mathrm{Pb})$. However, zinc $(\mathrm{Zn})$ show significant values in all samples. The highest $\mathrm{Zn}$ content was recorded for sample B80 with $107.6 \mathrm{mg} / \mathrm{L}$. The analysis results in negative value indicate that the content of heavy metals is too low and cannot be detected by ICP-OES.

Table 4 - Heavy metal content of the compost sample $(\mathrm{mg} / \mathrm{L})$

\begin{tabular}{ccccccc}
\hline Sample & Cd & $\mathrm{Cr}$ & $\mathrm{Cu}$ & $\mathrm{Ni}$ & $\mathrm{Pb}$ & $\mathrm{Zn}$ \\
\hline A60 & n.d & n.d & 0.017 & n.d & n.d & 1.243 \\
A70 & n.d & n.d & 0.010 & n.d & n.d & 15.50 \\
A80 & n.d & n.d & n.d & n.d & n.d & 22.78 \\
B60 & n.d & n.d & 0.068 & 2.317 & n.d & 12.06 \\
B70 & n.d & n.d & n.d & n.d & n.d & 3.098 \\
B80 & n.d & n.d & n.d & 3.484 & n.d & 107.6 \\
C60 & n.d & n.d & 0.075 & 2.649 & n.d & 2.011 \\
C70 & n.d & n.d & n.d & n.d & n.d & 38.28 \\
C80 & n.d & n.d & n.d & n.d & n.d & 28.59 \\
\hline
\end{tabular}

* n.d: not detectable

\section{Conclusion}

This study reveals that the composting method using the mechanical crusher machine is an easy and practical method for reducing waste generation. The machine enables to reduce the time consumption in producing compost than the conventional method. Furthermore, it was found that the mixing of landscape waste with EM is a good combination to be used in the composting process. The characterization of the sample for temperature and $\mathrm{pH}$ demonstrate to be in the acceptable range for fertilizer. However, the moisture content for all samples is low except for sample B80, C60 and 
C70 in the first week with 52\%. The $\mathrm{C}$ : $\mathrm{N}$ and $\mathrm{C}$ : P ratio was higher than the optimum due to the uses of carbon tape to mount the sample in EDX analysis. The highest $\mathrm{N}$ content was recorded at $32.9 \mathrm{mg} / \mathrm{L}$ for sample C60. While for $\mathrm{P}$ and $\mathrm{K}$ content were $11.32 \mathrm{mg} / \mathrm{L}$ and $77300 \mathrm{mg} / \mathrm{L}$, respectively in sample A60. All the samples had low heavy metals contents except for zinc. The results obtained from this study show that different concentrations of EM and different temperatures produced a different quality of compost. The higher the concentration of EM, the higher the content of $\mathrm{C}$, $\mathrm{N}$, and $\mathrm{P}$. Thus, the compost produced is suitable to be used as fertilizer.

\section{Acknowledgement}

The authors wish to thank UTHM for the financial support from Tier 1 grant (H213) and Ministry of Higher Education (MOHE), Malaysia for the financial support from FRGS grant (FRGS/1/2019/TK10/UTHM/03/3).

\section{References}

[1] Tan, S.T., Ho, W.S., Hashim, H., Lee, C.T., Taib, M.R. \& Ho, C.S. (2015). Energy, economic and environmental (3E) analysis of waste-to-energy (WTE) strategies for municipal solid waste (MSW) management. Energy Conversion And Management, 102, 111-120.

[2] Jannoura, R., Georg, R. \& Bruns, C. (2014). Organic fertilizer effects on growth, crop yield , and soil microbial biomass indices in sole and intercropped peas and oats under organic farming conditions. European Journal of Agronomy, 52, 259-270.

[3] Jayasumana, C., Fonseka, S., Fernando, A., Jayalath, K. \& Amarasinghe, M. (2015). Phosphate fertilizer is a main source of arsenic in areas affected with chronic kidney disease of unknown etiology in Sri Lanka. SpringerPlus, 4(1), 90.

[4] Yang, Z.C., Zhao, N., Huang, F. \& Lv, Y.Z. (2014). Long-term effects of different organic and inorganic fertilizer treatments on soil organic carbon sequestration and crop yields on the North China Plain. Soil and Tillage Research, 146, 47-52.

[5] Landscape Waste Collection (2019). Retrieved from https://www.normal.org/799/Landscape-Waste on 12 January 2020.

[6] Singh Brar, B., Singh, J., Singh, G. \& Kaur, G. (2015). Effects of Long Term Application of Inorganic and Organic Fertilizers on Soil Organic Carbon and Physical Properties in Maize-Wheat Rotation. Agronomy, 5, 220 38.

[7] Bary, A., Assistant, S.S., Soil, E. \& Emeritus, S. (2016). Fertilizing Farmland with Yard Trimmings from Landscape Maintenance. Washington State University Extension, 1-10.

[8] Brown, S. (2016). Greenhouse gas accounting for landfill diversion of food scraps and yard waste. Compost Science \& Utilization, 24(1), 11-19.

[9] Karunarathna, B. \& Seran, T.H. (2016) Field Evaluation Of Cattle Mannure Along With Effective Microorganisms On Growth And Yield Of Capsicum (Capsicum Annum L). International Journal of Advanced Research and Review, 1(4), 10-18.

[10] Ncube, L., B. Zhao, M. O. Brutsch, \& H. J. Van Niekerk. (2017). Response Of Swiss Chard And Soil Properties To Co-Application Of Different Fertilisers With Effective Microorganisms. Applied Ecology And Environmental Research, 15(4), 1009-1022.

[11] Mengistu, T., Gebrekidan, H., Kibret, K., Woldetsadik, K., Shimelis, B. \& Yadav, H. (2018). Comparative Effectiveness of Different Composting Methods on the Stabilization, Maturation and Sanitization of Municipal Organic Solid Wastes and Dried Faecal Sludge Mixtures. Environmental Systems Research, 6(1), 1-5.

[12] Chan, M.T., Selvam, A. \& Wong, J.W.C. (2016). Reducing Nitrogen Loss and Salinity During 'Struvite' Food Waste Composting by Zeolite Amendment. Bioresource Technology, 200, 838-44.

[13] Fatin, N., Saad, M., Nadrah, N., Zain, S., Ezlin, N., Basri, A. \& Zaini, N. S. M. (2013). Composting of Mixed Yard and Food Wastes with Effective Microbes. Jurnal Teknologi, 65(2), 89-95.

[14] Longji, Z., Yue, Z., Wenshuai, Z., Haixuan, Z., Xiaomeng, C., Yingjun, L., Dan, W., Zimin, W. (2019). Roles of Bacterial Community in yhe Transformation of Organic Nitrogen Toward Enhanced Bioavailability During Composting with Different Wastes. Bioresource Technology, 285, 121326.

[15] Mansi, R., Meenakshi, N., Babita, K. (2020). Microbes as vital additives for solid waste composting. Heliyon, $6(2), 1-11$.

[16] Margenot, A.J., Calderón, F.J., Bowles, T.M., Parikh, S.J. \& Jackson, L.E. (2015). Soil Organic Matter Functional Group Composition in Relation to Organic Carbon, Nitrogen, and Phosphorus Fractions in Organically Managed Tomato Fields. Soil Science Society of America Journal, 79, 772-82.

[17] AL-Saedi, Z.Z. \& Ibrahim, J.A.K. (2019). Evaluation of Heavy Metals Content in Simulated Solid Waste Food Compost. Journal of Engineering, 25, 62-75. 